\title{
Research Activity as an Integral Component of Engineering Education
}

\author{
M.V. Kuimova ${ }^{1}$, D.D. Burleigh ${ }^{2}$, Yu.Yu. Arnst ${ }^{1}$, A.E. Sentsov ${ }^{3}$ \\ ${ }^{1}$ National Research Tomsk Polytechnic University, Tomsk, Russia \\ mkuimova@mail.ru \\ ${ }^{2}$ La Jolla Cove Consulting, San Diego CA 92117, USA \\ ${ }^{3}$ National Research Tomsk State University, Tomsk, Russia
}

\begin{abstract}
The international aerospace industry needs to hire specialists who possess a broad range of skills and are able to work independently in a diverse, multi-disciplinary team, generate innovative ideas, solve non-standard problems and make important decisions. To meet new challenges, universities promote active learning and encourage students to participate in research activities. This paper studies the organization of research activities at universities, and factors that benefit their productivity. It also presents the results of a short survey among bachelor students of the Institute of Non-Destructive Testing, Tomsk Polytechnic University, showing their interest and active participation in research work.
\end{abstract}

Keywords - creativity; engineering education; engineering knowledge; life-long learning; research activities.

\section{Introduction}

Continuous improvement and development is essential in modern society. Society requires educated active individuals who are able to act independently, make decisions quickly, and adapt to the changing conditions of industry and the marketplace. Therefore, successful specialists in the global aerospace industry realize the need to be skilled in communication, problem-solving and research; they recognize the need for continuous education and learning. The modernization of higher education is focussed on the development of graduates' professional competence, and this must include experience in research. Research is an educational activity shared between students and teachers. It contributes to the education of a creative, professionally competent engineer who is wellprepared for the labor market.

\section{Related literature}

Research requires a combination of academic, scientific and educational activities. It is an essential component in the education of engineers. Introducing engineering students to scientific activities helps to develop university science departments, helps improve students' theoretical and practical knowledge, and contributes to the preparation of well-qualified engineering specialists. Involvement in research encourages advanced study and leads to learning and the acquisition of additional skills [Badley, 2002; Prince, Felder \& Brent, 2007]. It furthers the acquisition of research skills and teaches students how to make the best use of their time [Kremer \& Bringle, 1990; Lino \& Duarte, 2011]. Research activities require the organization of activities for problem solving [Knodt, 2000; Brew, 2003], teamwork, resource management and data management. It encourages communication skills, and introduces students to the latest topics in science and technology. It motivates students to pursue further education, and reveals the need for continuous learning and self-improvement. It helps students prepare for their chosen career in engineering [Wissey, 2000; Redish \& Smith, 2008; Martinez, Romero, Marquez \& Perez, 2010; Seetha, 2012; Di Carlo, Barsics \& Moitroux, 
2013; Ruchina, Kuimova, Polyushko, Sentsov \& Zhang Xue Jinc, 2015].

\section{Discussion and findings}

Universities compete for status as leading centers of research and education, and they view research as the main factor that distinguishes one university from another, and helps attract high caliber students, faculty members and scholars [Arai, Cech, Chameau, Horn, Mattaj, Potocnik \& Wiley, 2007; Mafenya, 2014]. The research activity augments the educational process, as it promotes the acquisition of important knowledge and experience in engineering, develops creativity, and expands the horizons of the student. Students' research activity is intended to provide scientific specialists with higher education, to identify capable students for graduate studies, and to update the scientific and pedagogical staff of the university.

Students' research activities include two interrelated areas.

- Teaching students the elements of research, organization and methods of scientific creativity.

- Research carried out by students under the guidance of professors from various university departments.

Currently, universities work hard to develop students' research skills and motivate them towards advanced studies and research activities. The importance of this work is reflected in educational curriculum of bachelors, masters, doctoral, and post-graduate students.

Research activities are carried out by means of:

1) Activities planned under the educational curriculum, including writing reports, preparing for seminars, defense of coursework, bachelor/master/doctoral thesis, industrial career placement, etc. The use of innovative teaching methods in education helps students enjoy research work. The introduction of research activities in routine laboratory work requires students to formulate a plan, review relevant literature, perform mathematical calculations and analysis of the results, write a report and present the results of the research.

2) Activities performed on the student's own initiative:

- Taking the above-mentioned course(s) on the theory of research and its implementation;

- Participation in competitions, conferences, scientific clubs, creative projects, grants, etc.

For example, students' participation in scientific research conducted by their department is a very productive form of extra-curricular activity. Typically, a group engaged in the solution of a certain scientific and technical task consists of students from different majors or departments. The work is performed according to a schedule approved by their scientific supervisor. The students' work is guided by teachers, scientists, engineers and graduate students working in the group. This collaboration ensures succession, continuity and a clear organization for the work.

An involvement in research activity provides a defined learning path for the student and motivates students to learn and to develop the skills to locate and use scientific information for a specific project. This ability can be important for success in an engineering career.

The productivity of research activities depends on a number of factors, including the following:

- Availability of infrastructure for research;

- Information Technology support systems;

- Capabilities, qualifications and professionalism of the teaching staff;

- Use of innovative educational technologies;

- Material stimulation; 
- Motivation and encouragement by the faculty.

A number of facts influence the effectiveness of students' research work: internal demand for research activities, personal interest to carry out the research, some research experience and inherent personality specific skills. The content and structure of students' research activities should agree with the logic of the educational process; determine the continuity from course to course, from department to department, from one discipline to another. The gradual increase in the volume and complexity of students' acquired knowledge and skills provides the development of:

- Scientific outlook and methods of scientific research;

- Initiative and ability to apply theoretical knowledge in practical work;

- Creative thinking and students' individual abilities in solving practical problems;

- Students' scientific and social mobility.

The goals of research activity are to promote fundamental learning, the use of scientific research methods and technology and compliance with the syllabus.

The teacher should use an individual approach in organizing research work, taking into account the student's level of subject knowledge, intellectual development, work pace, individual educational activity, etc. His main task is to cultivate enthusiasm for research, persistence, perseverance and independent thought. Scientific research work may also improve the student's desire to participate more intensively in scientific work. In collaboration with the teacher, a student develops an ability and need for partnership and the pursuit for a productive and effective relationship. As a side benefit, it may decrease feelings of isolation and other negative factors affecting the mental health of the student. Engineering students may be somewhat more inclined to such feelings than liberal arts students, as the latter tend to be more involved with social activities.

The success of students' research work depends largely on the universities' focus on status. Every university has departments responsible for the support and encouragement of talented students. As a reward for special achievements, students may be awarded honorary diplomas or cash prizes. They may also be invited to participate in prestigious exhibitions, conferences, competitions and Olympiads. Students who successfully combine active research work with good academic performance may be invited by the Academic Council of the university to enroll in postgraduate study.

To study the students' attitude on research activities and to determine which activities they participate in most often, we performed a survey among 39 third-year engineering students in bachelor degree programs at the Institute of Non-Destructive Testing (NDT) at the Tomsk Polytechnic University (TPU).

The following are the questions asked and students' answers.

1) Which activity is the most important to you?

Classroom activities $(43.6 \%)$

Scientific research work (28.2\%)

Out-of-class learning activity (23.1\%)

Independent work $(5.1 \%)$

2) In which events have you participated? (answers may include more than one option)

Scientific conference $(87.2 \%)$

Research competitions $(76.9 \%)$

Meeting with recognized scientists $(43.6 \%)$

Olympiads $(20.5 \%)$

Discussion clubs $(5.1 \%)$

Grants $(2.6 \%)$ 
3) What is the most difficult for you in a research project? The choice of ...

Scientific event $(92.3 \%)$

Scientific supervisor $(5.1 \%)$

Field of study $(2.6 \%)$

4) What motivates your participation in research activities?

Prestige $(51.3 \%)$

Educational benefits $(20.5 \%)$

Desire to develop and learn new useful skills (15.4\%);

Financial benefits (12.8\%)

5) Do you plan to continue your education and enter a Master program?

Yes $(97.4 \%)$

No $(2.6 \%)$

Thus, the findings show that third-year TPU students are interested in actively participating in research activities. The majority of them consider prestige and educational benefits as the most important and motivating. Most of the respondents plan to continue their education beyond their bachelor's degree. The results have shown that students have difficulty in choosing scientific event that is probably due to insufficient information or inattentive attitude to the information and poor motivation.

\section{Conclusion}

The development of students' research activities is of vital importance to the educational process. It is a continuous augmentation to the educational process. Students' research activity enhances the image and reputation of the institution, teaches the students to balance collaborative and individual work and contributes to international professional mobility. Research is organized by university departments to attract students to scientific and research activities, foster their knowledge, develop innovative thinking and to provide an opportunity to participate in international research projects, grants and programs. The ability of young people to not only maintain a certain level of knowledge, but also generate new knowledge and apply it in practice positively influences the country's future, its economic development and quality of life.

\section{References}

Badley, G. (2002). A Really Useful Link Between Teaching and Research, Teaching in Higher Education, Volume 7, Issue 4, pp. 443-455.

Prince, M.J., Felder, R.M. \& Brent, R. (2007). Does Faculty Research Improve Undergraduate Teaching? An Analysis of Existing and Potential Synergies, Journal of Engineering Education, Volume 96, Issue 4, pp. 283-294.

Kremer, J.F. \& Bringle, R.G. (1990). The Effects of an Intensive Research Experience on the Careers of Talented Undergraduates, Journal of Research and Development in Education, Volume 24, Issue 1, pp. 1-5.

Lino, F.J. \& Duarte, T.P. (2011). Research skills enhancement in future mechanical engineers, 2011 IEEE Global Engineering Education Conference, EDUCON 2011, pp. 1088-1095.

Knodt, E.A. (2000). When Teaching Informs Research: Learning from Our Students, Teaching English in the Two-Year College, Volume 28, Issue 2, pp. 207-211.

Brew, A. (2003). Teaching and Research: New Relationships and Their Implications for Inquiry-Based Teaching and Learning in Higher Education, Higher Education Research \& Development, Volume 22, Issue 1, pp. 3-18.

Wissey, T.W. (2000). Enhanced skills for engineers, Proceedings of the IEEE, Volume 88, 
Issue 8, pp. 1367-1370.

Redish, E.F. \& Smith, K.A. (2008). Looking Beyond Content: Skill development for engineers, Journal of Engineering Education, Volume 97, Issue 3, pp. 295-307.

Martinez, M., Romero, G., Marquez, J. \& Perez, J. (2010). Integrating teams in multidisciplinary project based learning in mechanical engineering, IEEE EDUCON Engineering 2010 - The Future of Global Learning Engineering Education, pp. 709-715.

Seetha, Sh. (2012). Communication Skills for Engineers in Global Arena, International Journal on Arts, Management and Humanities, Volume 1, Issue 1, pp. 1-6.

Di Carlo, P., Barsics, J. \& Moitroux, C. (2013). Contribution of research \& development to student's motivation, Proceedings of the 24th International Conference on European Association for Education in Electrical and Information Engineering, EAEEIE 2013, pp. 4247.

Ruchina, A.V., Kuimova, M.V., Polyushko, D.A., Sentsov, A.E. \& Zhang Xue Jinc. (2015). The Role of Research Work in the Training of Master Students Studying at Technical University, Procedia - Social and Behavioral Sciences, Volume 215, pp. 98-101, doi:10.1016/j.sbspro.2015.11.580.

Arai, K., Cech, T., Chameau, J.L., Horn, P., Mattaj, I., Potocnik, J., \& Wiley, J. (2007). The future of research universities. Is the model of research-intensive universities still valid at the beginning of the twenty-first century?, EMBO Reports, Volume 8, Issue 9, pp. 804-810.

Mafenya, P.N. (2014). Challenges Faced by Higher Education Institutions in Research Skills Development: A South African Open and Distance Learning Case Study, Mediterranean Journal of Social Sciences, Volume 5, Issue 4, pp. 436-442. 